\title{
GETTING IT TOGETHER IN BURGUNDY, 1675-1975
}

\author{
CHARLES TILLY
}

\section{What the Archives Say*}

The municipal archives of Dijon occupy several cluttered rooms in the grand old palace of the Dukes of Burgundy. The archives' main door looks out onto the elegant semicircle of the Place de la Libération, built in the late seventeenth century as the Place Royale. Readers in the high-ceilinged salle de travail have no trouble tallying arrivals and departures. A strident bell sounds in the room so long as the outside door is open. The interruption usually lasts five to ten seconds, as the newcomer closes the street door, crosses the anteroom, fumbles with the inner door, and enters. In bad weather arrivals are more disruptive; after the long bell stops sounding, visitors stomp their feet unseen, remove their boots and hang up their raincoats before presenting themselves for inspection. Exists are equally distracting, for they mirror the entries precisely: thud, shuffle, stomp, ring.

Distractions, however, are few. Not many people come to the archives: a few city employees, an antiquarian or two, an occasional student from the university, now and then an itinerant historian. Those few have riches before them. They have the surviving papers of the capital of Burgundy, both as an independent power and as a major French province. The archives are especially full up to the point at which the centralization of the Revolution shifted the balance of power, and paperwork, toward the state's own bureaucracy.

Among the thousands of bundles in the pre-revolutionary collection, 167 fall into series I. Series I includes Police, in the broad old-regime meaning of defense against all manner of public ills. Its topics are sanitation, public health, fire protection, asylums, pursuit of beggars, vagrants and criminals,

Center for Research on Social Organization of the University of Michigan

*I am grateful to the National Science Foundation for financial support, to the archivists of the departmental and municipal archives of Dijon for aid, and to Martha Guest for help with bibliography. This is an edited version of Working Paper 128, Center for Research on Social Organization, University of Michigan. (c) 1977 Charles Tilly. 
control of games, gatherings and public ceremonies. Nineteenth-century archivists sorted the papers by subject matter, by rough time period and then usually by affair, event, session, or whatever other subdivision the organization producing the records had used in its own work.

The series contains reports of the activities of the chassecoquins, the seventeenth-century officials assigned, literally, to chase coquins (scalawags and ne'r-do-wells) from the city. It includes more details than most of us would care to read concerning the official surveillance of the wine-harvest, in that great wine region, from 1290 onward. It has a great mass of reports-and, especially, of invoices-from four centuries of publicly-sponsored celebrations. We see the elaborate preparations for the annual fireworks of St. John the Baptist Day, including a note from 1642 on the "Malefactors who set off the fireworks when the mayor was going to light them himself as usual ..." (A. M. [Archives Municipales] Dijon I 43). We watch the great funeral processions, including the sixty musicians who played and sang the funeral mass composed for the Dauphin in 1711 (A. M. Dijon I 48). We witness incessant pompous entries into the city of dukes, duchesses, queens, kings, princes and ambassadors: King Charles VI in 1387, Duke Charles the Bold in 1470, King Henry IV in 1595, Louis XIV and the Queen in 1674, and dozens of others (A. M. Dijon I 5-36). In short, the very tapestry of Dijon's public life.

Those concerned less with kings and more with the participation of ordinary people in the city's public life also find much to think about in series I. The fifty-four affairs in bundle I 119, for example, deal with "seditions" and other serious offenses against public order between 1639 and 1775. In the century before the Revolution, "sedition," "emotion," and "mutiny" were common terms for events which later observers would probably have called "riots" or "disturbances." Unsympathetic observers, that is. "Sedition," "emotion," "mutiny," "riot" and "disturbance" are terms of disapproval, power-holders' words. The documents of Bundle I 119 breathe life into the shapeless words. In 1668 , for example, they show the municipality issuing a warning against unnamed people who had spread the rumor that the major tax, the taille, was to be increased, and forbidding the populace "to assemble or form a crowd day or night on any pretext, or to incite the people to sedition, on pain of death..." The anonymous enemies of the people had allegedly said "they needed a Lanturelu."

Lanturelu was a popular song of the 1620 s which gave its name to a popular rebellion of the 1630s. Back then, Richelieu and Louis XIII had announced the elimination of Burgundy's privileged tax status. On the 27th and 28th of February 1630, a hundred-odd armed men led by winegrower Anatoire 
Changenet, plus a crowd of unarmed women, men and children, gathered in the streets of Dijon. (Gens de bas étage-lowly folk-city officials called them later. Anatoire Changenet himself had just served as King of Fools in the city's Mardi Gras festivities.) Among other things, the crowd sounded the tocsin, sacked the houses of royal officials, and burned a portrait of Louis XIII. They are supposed to have shouted "Long live the Emperor"-the Habsburg descendant of Burgundian Charles the Bold, and mortal rival of the French king. Dijon's mayor hesitated a day before calling out the militia, which killed ten or twelve of the rebels in the process of dispersing the crowd. The King retaliated by imposing a state of siege, ordering the winegrowers to move outside the city walls, requiring a large payment to the victims of property damage, further abridging the city's privileges, and staging, in April 1630 , a humiliating confrontation with local dignitaries. The Parlement of Burgundy, doing its part, condemned two leaders of the rebellion to hang. That was a Lanturelu.

No Lanturelu occurred in 1668, yet seventeenth-century Dijon had its share of seditions, emotions and mutinies. In February 1684 the winegrowers again took their turn. The public prosecutor described the event as "... a popular sedition that three or four hundred winegrowers wanted to start in the city by their enterprise of gathering together, marching through the city with beating drum and unfurled banner without any authorization to do so..." Later details in the prosecutor's own account set the number of marchers at something over a hundred. (The exaggeration at the start of the account may well reflect the fact that in an encounter between city officials and the winegrowers at the Guillaume Gate, as the prosecutor tells the story, "it was only by some sort of miracle that none of them was assaulted, notably the aforesaid public prosecutor by one of the seditioners, who was at the head of the crowd and got ready to strike him with his pruning-knife.") The winegrowers assembled to the drumroll, as people often assembled for special occasions in those days. Among the leaders, as in 1630, was a winegrower named Changenet-this one the Jean Changenet who later described himself as "winegrower in Dijon, rue Chanoine, twenty-nine years old, professing the Apostolic Roman Catholic religion."

The winegrowers went en masse to Champmoron wood, which belonged to the nearby Carthusian monastery. There they gathered firewood, then returned to the city. They were on their way back through the gate when they met the small band of officials who had come to stop them. Hilaire Edouard Demouchy (conseiller $d u$ roi, trésorier de France and, most important, leaseholder of Champmoron wood) filed a formal complaint asking for redress, prosecution and official rejection of the winegrowers' claim to the 
firewood. The authorities clapped a dozen leaders of the march, including Jean Changenet, in jail. A few days later the mayor and council received a petition reading:

You are asked by some of the poor winegrowers and some of your most faithful servants among the poor people of this city to have pity and compassion for the poor wretches who are in jail here for having assembled at the sound of the drum to go to the woods, which was done without any thought of offending you but only to give the group strength against those who wanted to stop it from cutting wood...

In their own petition, the twelve imprisoned winegrowers said they had been arrested "... while returning from Champmoron wood where they had gone to cut firewood, along with many other winegrowers from the city who claimed they had the right to do so as a result of concessions granted to the winegrowers by the Duke of Burgundy, as has often been practiced in the past when required by bad weather and hard winter, as in the present year where the need is great." Part of the transcript from the interrogation of forty-year-old Pierre Reignaut runs as follows:

Asked why they banded together thus to go to the wood if they already had the right to cut there.

Replies that the reason they went to the aforesaid wood in large numbers was that the first persons to go had been chased out by the valets of the Carthusian fathers and in the fear that the same thing would happen again the greater part of the winegrowers had assembled in order to maintain their right to cut in the aforesaid wood.

After some weeks in jail, the twelve prisoners went free on their promise of good behavior. Their action apparently stirred the municipality: the following year the city sued the Carthusians for enforcement of the winegrowers' right to gather wood.

The traces of many other events appear in that rich bundle of seditions: another confrontation over firewood in 1696 (but this one over the royal toll on wood entering the city); threatening, demanding gatherings of women during the great hungers of 1693 and 1709; seizure of grain wagons by a crowd of "more than a thousand" in 1770; still others earlier and later. The events portray a Dijon in which some issue brought crowds to the street and into confrontation with the authorities every three or four years. 


\section{The Seventeenth Century Confronts the Twentieth}

As I pored over the papers of Bundle I 119 one day in the spring of 1975, Monsieur Savouret, Madame Jacquette and Monsieur Benoist, the staff of the Dijon archives, were busy about their work in the reading room. Gradually a muffled sound outside resolved itself into chanting, crescendo. "What is it?" I stupidly asked my companions. We went to the windows, which gave us a view into the Place de la Libération through the great barred gate of the palace. People were marching outside.

I rushed to the exit. The indefatigable bell signaled my translation from the seventeenth century to the twentieth. Up the street came several hundred young men and women, in uneven ranks. Some carried an effigy of a man, others hoisted signs and banners. They continued to chant loudly. A marcher thrust a handbill at me. The issue, it turned out, was the future of students preparing to teach sports and physical education. The dummy appeared to represent M. Mazeaud, the Secretary of Youth, Sports and Leisure, who was proposing a tiny budget for physical education as well as the removal of compulsory sports from public schools. That would seriously curtail these students' job prospects. The demonstrators were on their way to the Place de la République for a rally, as students in other French cities were likewise on the way to their Place de la République for rallies. An hour or so later, they passed the archives again, on the way back to the university area. The undisciplined ranks and disciplined chants had dissolved, but the demonstrators still shourted and cheered. Gradually their voices gave way to the ordinary noises of the street. My thoughts turned back three centuries to 1675 .

Are the turbulent events of 1675 and 1975 knots on the same long thread? The event in the archives and the event on the street both consist of people banding together to act on their shared grievances, hopes and interests. That banding together-let us call it collective action for short-has its own history. As people's grievances, hopes and interests change, and as their opportunities for acting on them change, obviously their ways of acting collectively change as well. In between interest and opportunity, and less obviously, comes a third factor: organization. Whether we are watching seventeenth-century winegrowers or twentieth-century students, we notice that they do not seize every opportunity to act on their interests, and do not react to every opportunity in the same way. How they are tied to each other, what ways of acting together are already familiar to them, and which sorts of news they have alerted themselves to, affect how much they act, in what manner, and how effectively. 
The Dijon winegrowers had a pressing need for firewood that cold winter. Indeed, wood shortage was becoming a critical problem in all Burgundy as forests passed into private hands and small wood-burning forges multiplied. The winegrowers had the slim opportunity offered by their claim to a privilege granted by the Dukes of Burgundy; that opportunity was disappearing as the rise of bourgeois property squeezed out the old shared rights to glean, pasture, forage or fish on local territory. Compared with other groups of poor people in Dijon, winegrowers had the advantages of coherent organization: extensive ties sustained by daily contact, relatively effective leadership, previous experience in acting together. The history of collective action clearly has four components: interest, opportunity, organization and action itself. All four vary from group to group, place to place, time to time, problem to problem.

Interest, opportunity, organization and action: a large, rich historical agenda. The turbulent events whose traces have survived in seventeenth-century police archives are obviously a peculiar sample of all the century's collective action, and therefore of the interests, opportunities and organization at work. Nevertheless those events immediately identify lineaments of seventeenth-century French collective action, and its context, which differ significantly from those of the twentieth century.

\section{Collective Action in Seventeenth-Century Burgundy}

Dijon and Burgundy had come to the French crown with Louis XI's defeat of Charles the Bold, Duke of Burgundy, at the end of the fifteenth century. Charles' successors, the Habsburg emperors, continued to press their claims by word and sword. Adjacent to the Habsburg lands of Franche-Comté, Burgundy was a military frontier and a favorite sixteenth-century battleground. After the decline of the direct military threat from outside came a division from within; Burgundy ran red with the blood of sixteenth-century wars between Protestants and Catholics. The wars of the League, the dynastic struggles for control of the duchy which blended into the Thirty Years War, popular insurrections continued through the tumultuous time of Lanturelu to the mid-seventeenth-century rebellion of the Fronde. During the early years of the Fronde, many Burgundian notables sympathized, and even conspired, with the insurgent governor of Burgundy, the Prince of Condé. From 1651 to 1653 the supporters of Condé raised an armed rebellion which only ended with the royal siege of Dijon and the conquest of the fort of Bellegarde, at Seurre. With the victory of Louis XIV and Mazarin over the Frondeurs came the end of Burgundy's age of war and large-scale rebellion. 
Thus the middle of the seventeenth century marks an important transition. The transition shaped the development of popular collective action in Burgundy as well as the province's general political history. Before, every popular movement provided an opportunity for some fragment of the ruling classes to press its advantage against the Crown. The clientele of one great noble or another were frequently the basic units among the warriors or rebels. Crowds which moved against royal exactions, such as the crowd led by Anatoire Changenet in 1630, found sympathy or even support among the local authorities. With the decisive subordination of local officials to royal power in the later seventeenth century the chances for implicit or explicit alliance between officials and plebeian rebels greatly diminished. Ordinary people continued to act. But the shift of the process of extension of royal power from a stage of great uncertainty and cross-class alliances to a stage of crunching but inexorable growth left ordinary people to act alone in the name of their particular rights and privileges. The authorities, quelled or coopted, increasingly treated popular gatherings as dangerous sources of "sedition."

During that seventeenth century, then, the interests, opportunities, organization and collective action of Burgundy's ordinary people were changing. Their interests shifted as a warmaking monarchy pressed them increasingly for taxes to support its growing armies, and as the bourgeois of Dijon increased their domination of the region's land and economic activity. Their opportunities to act on those interests altered, mostly for the worse, as the importance of patronage and the possibility of alliance with regional power-holders declined. Their organization changed with the increasing proportion of landless workers and the stratification of rural communities. As a result, the collective action of ordinary people changed as well.

In the years after the winegrowers' invasion of Champmoron wood, a number of the incidents which left their remains in Dossier I 199 and adjacent archives involved popular resistance to demands of the state. In 1691, a royal edict prescribed yet another creation and sale of offices for the profit of the Crown. This time there were two offices of jurés crieurs des obsèques et enterrements: public registrars of funerals and burials. They sold for 6,000 livres. Word spread that the funeral fees of the poor would therefore rise prohibitively. Menacing crowds formed outside the home of the purchasers of the offices, insulted them, and called again for a Lanturelu (A. M. Dijon B 329). In 1696, firewood was again the issue, and the Porte Guillaume again the site of the crucial confrontation. This time countrymen delivering wood to the city pried open the gate with pokers and crowbars, in order to avoid paying the new tax of eight sous per bundle 
(A. M. Dijon I 199). During the last years of the century, as Louis XIV pursued his wars against Spain, we see rising complaints and resistance against conscription, impressment, billeting and military foraging among the reports of Te Deums for royal victories.

During those same years the food riot elbowed its way to the leading position among the more turbulent forms of popular collective action. From the 1690 s to the $1840 \mathrm{~s}$, some form of the food riot was no doubt the most common setting for violent conflict above the scale of the barroom brawl in Burgundy, as in the rest of France. 1693 and 1694 brought Burgundy innumerable instances of the food riot in all three of its major forms: the popular inventory and seizure of grain held in storage by dealers and private parties; the forced sale of grain or bread at a price below the current market; the blockage of grain shipments destined to leave or pass through on their way to other markets. In 1693, the combination of an inferior harvest and the pressure to supply the French armies at war in Germany emptied the Burgundian markets, drove prices up and squeezed the poor. When they could, the authorities of Dijon and other cities responded to the rioters in kind: they inventoried and commandeered the grain on hand, blocked shipments, and arranged the public sale of food below the market price.

For the most part, the so-called rioters were either substituting themselves for the authorities or forcing them to do their duty. Sometimes, however, the crowd wreaked or threatened vengeance. A declaration of the Parlement posted on the 20th of August 1693 stated that "... yesterday from 8 to 10 P.M. many wives of winegrowers and laborers gathered together and threatened to kill and to set fire to houses because there is only a small amount of grain in aforesaid city, and it cannot be enough to feed all the residents ..." As usual, the poster went on to forbid "... all inhabitants of Dijon, of whatever sex or age, to gather in the streets or any place else by day or night, or to use threats, violence or inflammatory language, on pain of death ..." (A. M. Dijon I 119).

Food riots flourished in the next century. One of the greatest struggles over subsistences in French history occurred in 1709. Again the coincidence of a bad harvest and extraordinary demand from armies abroad put acute pressure on local supplies. Again the crisis gave merchants and local officials a hard choice: give priority to the local poor by commandeering the local stocks and selling them at controlled and subsidized prices, or accede to the higherpriced, and officially-backed, demand from outside. As the eighteenth century moved on, royal policy favored the armies and the national market with increasing zeal and effectiveness; the desire of merchants and officials to favor 
the locals wilted obligingly. Since the landless poor were actually increasing as a proportion of the general population, the pressure on local communities increased despite a slow rise in agricultural productivity. The widespread food riots of the eighteenth century replied to that pressure.

The structure of the classic food riot-commandeering, blocking and/or selling below market-makes it clear that it was a means of forcing the merchants and officials to favor the locality over the armies and the national market. The procedure often worked. The structure of the individual event does not make it quite so clear that it was a tool to block the advance of mercantile capitalism. In that regard, it was at best a monkey wrench in the machinery: stopping the gears now and then, knocking out a few teeth, but also encouraging the development of tougher machines and protective screens.

The form of food riot that grew up in the late seventeenth century nicely illustrates the place of changing interests, opportunities and organization in changes of collective action. The interest of the local poor (and, to some extent, their patrons) in local priority over the food supply was growing as the interest of the Crown and larger merchants in freeing it from the local grasp increased. The opportunities of the poor were mainly negative, since they consisted of official failures to intervene in the local market as local authorities were supposed to. The change in organization in this case is relatively unimportant although there are some signs that groups such as Dijon's winegrowers were becoming more clearly aware of their distinctive and threatened class position. What is important is the persistence of local organization on the basis of which poor people pressed their claims to the food supply. This changing combination of interests, opportunities and organization produced the food riot as naturally as other combinations produced the tax rebellion, concerted resistance to conscription and attacks on enclosing landlords.

\section{To the Revolution}

If we were to inch forward through the eighteenth century, further changes in the surface of popular collective action would give us more indications of shifts in interest, opportunity and organization. To get a stronger sense of the changes still in store, however, let us leap a century from the 1690 s to the Dijon of the early Revolution. A National Guard report informs us:

Today 23 August 1790 , on the complaints brought by a number of citizens to the commander of the Volunteers' post at the Logis du Roy 
around 11 P.M. that someone (to the great scandal of right-thinking folk) had just sung, to the accompaniment of several instruments, a Romance or Complaint containing a funeral ode to the Marquis de Favras, outside the home of M. Frantin, a city official. We, Jean-Baptiste Roy, captain of Volunteers commanding the aforesaid post at the Logis du Roy, thought proper to form immediately a patrol to follow the group of musicians who we had been informed were heading toward the rue du Gouvernement and therefore led the aforesaid patrol to that street where we did in fact find the aforesaid group of musicians at the hour of midnight, stopped before the door of M. Chartraire, mayor of this city. Among them we recognized, and heard, M. Roche, a lawyer, singing to the accompaniment of a guitar and of several violins in the hands of MM. Propiac, Pasquirer and a number of others unknown to us, the Complaint of the aforesaid Favras, in which we noticed the language of the enemies of the Revolution, in that the author of the Complaint in his delirium dares to accuse the Parisian people of madness, and taking a prophetic tone announces that the people will get rid of the new system. Considering that a text of that type in which one is not ashamed to favor a traitor to the people such as the King's friend, sung at improper times in the most frequented neighborhoods of the city could only have for its object to incite the people to insurrection, and considering that it is urgent to prevent that mishap, we thought it was our duty to report the event to the general staff ... (A. D. [Archives Départementales] Côte d'Or L 386).

The comrade-in-arms of our commander at the City Hall post informs us that:

... a number of citizens of the city of Dijon, following a musical ensemble, passed before the City Hall; eight of the riflemen of the post of the aforesaid City Hall, drawn by the melody, followed the line of march, which ended in front of the home of the Mayor; there the musicians, seating themselves, sang a Complaint or Romance which seemed quite improper to the riflemen, in that they heard some words which could overturn public order ... (A. D. Côte d'Or L 386).

And as "seditious song" itself? The surviving text includes this verse:

Since you must have a victim

Blind and cruel people,

Strike, I forgive your crime,

But fear eternal remorse;

You will recover from madness;

And tired of a new system 
You will see my innocence

You will cry on my tomb.

Now, the Marquis of Favras was part of a plot to seize the King and spirit him away from the grasp of the Revolution. Betrayed by his fellow conspirators, Favras was hanged in the Place de Grève, in Paris, on 18 February 1790. One could hardly have a more counter-revolutionary hero. Confronted with such evidence of subversive activity, the National Guard's general staff leapfrogged the city council to make its report on the incident directly to the Department's administration; it appears that among the serenaders were some members of the city council itself.

The counter-revolutionary musicale connected with a whole series of demonstrations of opposition to the leaders and the symbols of the revolutionary movement in Dijon. There is, for example, that group of forty-odd citizens who "struck down the national cockade" in November, and who "provoked all the citizens" at the cafe Richard (A. D. Côte d'Or L 386). There is the group of customers at the Old Monastery cabaret who, two days later, insisted that three young men take off their national cockades (that is, their red, white and blue ribbons) before being served (A. D. Côte d'Or L 386). At that time the National Guard, municipal guardian not only of public safety but also of revolutionary sentiment, was campaigning for the obligatory wearing of the cockade. (The city council, at its meeting of 8 November 1790 , declared the request that its members wear the cockade on their chests "illegal and harassing": A. M. Dijon 1 D).

We should not conclude from these little run-ins, however, that Dijon was simply a counter-revolutionary haven. The capital of Burgundy had undergone a local revolution thirteen months before the mayor's serenade: an impeccably bourgeois revolutionary committee seized power from a council which was strongly attached to the Parlement, and therefore to old-regime institutions. A more conservative municipality came to office in the elections of January 1790. It faced an active patriotic Club speaking for the National Guard's leaders and the revolutionary committee of $1789 .{ }^{1}$ Other events displayed the revolutionary spirit in Dijon: the popular demonstrations of December 1790 against the so-called Fifth Section of the Amis de la Constitution, a reactionary club; the workers' gatherings around the municipal offices at the opening of the relief-work program in March 1791; the crowds of April 1791 which "formed in front of the churches of La Madeleine and La Visitation and went through the city to tear down coats of arms, pillars and ornaments attached to private houses and public buildings ..." (A. M. Dijon $1 \mathrm{D}$; A. D. Côte d'Or L 444). Dijon was a divided city, like many other French cities of its time. 
The conflicts which divided Dijon reappeared throughout France. Rather than flowing from a unanimous desire of the French people, the Revolution we know emerged from ferocious struggles in place after place. Their form, their combatants and their results varied with local social structure. The Revolution which occurred in Paris during July 1789 started a vast effort to centralize political power, opened up great opportunities for the organized segments of the bourgeoisie, stirred an unprecedented popular mobilization, encouraged a politicization of all sorts of conflicts. But the ramifications of the Revolution outside Paris posed particular problems in each locality, depending on the existing interests and organization. In the Loire, for example, the fundamental cleavage which led to the department's participation in the anti-Jacobin Federalist revolt separated two well-defined groups: the Montagnards, composed largely of workers and a bourgeois fragment, and a moderate majority coalition led mainly by the region's landholders. ${ }^{2}$ In the Vendée, a compact nucleus of merchants and manufacturers faced a formidable coalition of nobles, priests, peasants and rural workers. ${ }^{3}$ In Burgundy, the bourgeois fought against the resistance of the Parlement's adherents and the relatively radical demands of winegrowers.

Despite the diversity of these alignments, from them developed certain deep, common consequences: intense political participation on the part of the general population; a decline in the influence (and especially the official position) of priests and nobles; a rise in the political significance of the regional bourgeoisie; a promotion of conditions favoring capitalist property and production; a sharpening of awareness of connections between local conflicts and national power struggles; a concentration of power in a growing, increasingly centralized state. In looking at Dijon's little serenade of 1790 , we witness a small reaction to a very large transformation.

If the serenade was clearly part of the revolutionary struggle, it was just as clearly a piece of the eighteenth century. We have already noticed the importance of song to public displays of sentiment in the Lanturelu. But we have not yet noticed the widespread form of action which the 1790 night music most closely resembles. It is the charivari-often corrupted into "shivaree" in American English, and often called Rough Music in England.

\section{Charivari Before and After the Revolution}

The basic action of the charivari runs like this: assemble in the street outside a house, make a racket with songs, shouts and improvised instruments such as saucepans and washtubs, require a payoff from the people inside the house, then leave if and when the people pay. The words and action are mocking, 
often obscene. They describe and condemn the misdeeds of the house's residents. In its essential form, the eighteenth-century charivari was the work of a well-defined group which bore some special responsibility for the moral rules which the targets of the action had violated. The best known, and probably most widespread, examples concern familial, sexual and marital motality. One standard case is the noisy public criticism of an old widower who married a young woman. In such a case, the makers of the charivari ordinarily came from the young unmarried men of the community, who often comprised a defined, exclusive association: the youth abbey or its equivalent. In the case of moral offenses the payoff required was not always a simple gift or round of drinks. Sometimes the serenaders demanded the departure from the community of the tainted individual or couple. Sometimes the guilty parties left town.

Like most regions of Europe, Burgundy had its own version of the charivari, linked to a complex of local institutions. In Burgundian villages, the "bachelors' guilds" (compagnies de garçons) included all the unmarried men of twenty or more. The local bachelors' guild required a cash payment from young men as they reached the minimum age. It kept an eye on their love affairs and even told them which girls they had a right to court. It defended the village maidens from the attentions of men outside the guild. The bachelors' guild collected a substantial payment, in cash or in the form of a festival, from the young men who married and, especially, from outsiders and otherwise unsuitable men who dared to marry women from the locality. This last category of marriages was a common occasion for charivaris and brawls. In Burgundy, the same bachelors' guild often had responsibility for public bonfires in Lent and at other sacred moments of the year, gathered wood for that purpose, and had the right to collect a contribution from each household in compensation for its efforts. At the local scale, it was thus a significant institution which provided services, bound the young people together and exercised genuine social control. The charivari, for all its apparent quaintness and triviality, had profound roots in the regional culture.

In that light, the observer of Burgundy's political life after the Revolution notices some curious reflections of the old regime. Under the July Monarchy Dijon's police archives are jammed with old-fashioned charivaris. For example, in July 1834:

On the $22 \mathrm{~d}$ instant, toward 9 o'clock at night, some youngsters gave a charivari to the newlyweds-Baudry, a tailor, and Miss Ody-who did not give a ball; that fact occasioned a rather large gathering on the rue 
St. Nicolas, but did not produce any disorder, and the charivariseurs fled at the sight of the gendarmes (A. D. Côte d'Or 8 M 29).

The charivari's being police business was not entirely new, since even in the eighteenth century the municipal police intervened from time to time when a charivari was too raucous or too long. The intervention of the police nevertheless shows us the opening of a breach between bourgeois law and the law of popular custom.

Beside the usual applications of the charivari to the improperly married, furthermore, we find its use for explicitly political purposes. A police report from 8 September 1833 informs us that:

Yesterday evening the 7 th instant, toward nine o'clock, a charivari took place outside the Hotel du Parc on the occasion of the stopping in this city of a deputy named M. Delachaume, coming from Paris on his way to Châlons-sur-Saône, whither he went at four o'clock this morning. The charivari only lasted a few moments. It began on the rue des Bons Enfants, where the organizers, known to be republicans, assumed that M. Delachaume was having supper with one of his friends. But having learned differently, they went to the Hotel du Parc, where a crowd of more than 300 persons gathered at the noise they made. The noise soon stopped at the request of one of them, a certain Garrot, known to be a fiery republican; he raised various cries: $A$ bas le rogneur de budget, le con de député, etc. and other indecent words we could not make out. After those cries they left, along with the people whom the scandalous spectacle had attracted. With Mr. Garrot at the head of all these young people, most of them workers and some diguised in work clothes and others in straw hats, the group scattered and later gathered at the Republican Club located at the Place d'Armes over the Thousand Columns cafe (A. D. Côte d'Or 8 M 29).

A charivari? Certainly a transplanted one. The event retains some features of its form, but aims at a political enemy and operates under the guidance of a republican association with its headquarters a private room in a cafe. Those are nineteenth-century devices. Nevertheless, to the eyes of Dijon's captain of gendarmes, it is a charivari.

Another police report ten days later likewise sheds a revealing light on the nineteenth-century version of the charivari:

On the evening of the 18 th, it was said that a serenade would be given to M. Petit, deputy royal prosecutor, who had just resigned on refusing to 
make a search which took place at the offices of the Patriot, and also that a charivari would be given to the royal prosecutor, who ordered that search. The gendarme patrol was therefore sent to the homes of M. Petit and the royal prosecutor, but disorder was seen (A. D. Côte d'Or 8 M 29).

This juxtaposition of the serenade and the charivari tells us about another significant feature of these means of action: the existence of gradations of the performance running from very negative to very positive. One could organize a friendly charivari: a serenade. In fact, when the deputy-philosopher Etienne Cabet arrived in Dijon in Novermber 1833, "many young people" immediately gave him a serenade. During the festivities the innkeeper Mortureux was arrested for "seditious cries;" he had shouted "Long live the Republic" (A. D. Côte d'Or 8 M 29).

For another twenty years, the charivari continued to fill the police dossiers of Dijon--and, for that matter, of other French cities. After the revolution of 1848 , its irrevocable decline began. If you run through the dossiers of the Third Republic, you encounter plenty of actions of workers and peasants which attract police attention, but almost no trace of that once-flourishing ritual, in either its moral or its political form. So we are dealing with a form of action which did plenty of work for the ordinary people of the old regime, which adapted to different circumstances and to broad social changes, but which went into retirement in the age of unions, associations and political parties.

The existence of that range of applications of a musical sanction raises an interesting series of problems. First of all we notice the paradoxical combination of ritual and flexibility. As in every well-defined, familiar game, the players know how to modify, improvise, elaborate, even innovate while respecting the ground rules. From the Revolution onward, we see the players extending the charivari from its moral base to explicitly political affairs. The charivari is a well-defined means of collective action, parallel in that regard to voting, demonstrating, petitioning and striking. Like every means of collective action, the charivari has its own applications and its particular history. But at a given point in history it belongs to a familiar repertoire of collective actions which are at the disposal of ordinary people. The repertoire of collective actions therefore evolves in two different ways: the set of means available to people changes as a function of social, economic and political transformations, while each individual means of action adapts to new interests and opportunities for action. Tracing that double evolution of the repertoire is a fundamental task for social history. 


\section{How the Revolution Mattered}

What that trace shows makes quite a difference to our understanding of major political changes. We can, for example, imagine three different roles for the French Revolution in the transformation of collective action: as a hinge, as a milestone or as an episode. If it acted as a hinge, the Revolution changed the whole direction in which collective action was evolving. Thus Albert Soboul, despite some concessions to pre-revolutionary changes and to the general drift of history, declares that the Revolution "transformed French existence fundamentally, making it correspond to the views of the bourgeoisie and the owning classes." 4

Seen as a milestone, the Revolution marked but one stage among others in the course of a transformation already well begun, and continuing afterward. Michelet, for example, portrays an acceleration of the march of justice and of the French people under the Revolution. In his view, the acceleration reinforced the continuous movement of history, rather than contradicting, interrupting or even deflecting it.

Finally, if we see the Revolution as an episode, we claim that at most it broke the continuity of a set of social conditions which took hold again later as if the Revolution had not taken place. Although he does allow the Revolutionary period some peculiarities of its own, Yves-Marie Bercé's analysis of peasant uprisings from the sixteenth to the nineteenth century concludes that "the peasant risings of 1789-93 do not display any fundamental break with the prior pattern of communal revolts. They were in fact a survival of old forms, and did not mark the appearance of new forms of violence." 5

The notions of the Revolution as hinge, milestone or episode obviously apply to popular collective action as well as to social organization in general. Our historical promenade in the Dijonnais leads in the direction of the second notion: milestone rather than hinge or episode. The Revolution, that is, marked a stage of a process which was already visible in the eighteenth century and was still active in the nineteenth. The stage was crucial. The process itself was complex, including the resistance of local interests against the incursions of the state and of capitalism as well as the rise of different types of association as the bases of collective action, the nationalization of power struggles and a sort of politicization of collective action. These conclusions emerge at three different levels: from the study of the occasions of collective action from the mid-eighteenth to the mid-nineteenth century; from the analysis of the repertoire of collective action during the same period; and from reflection on the work of the Revolution itself. 
At the level of occasions for collective action, it is remarkable how much the defense of threatened interests outweighed the pursuit of hopes for a happier future. If in France as a whole the seventeenth century was the heroic age of tax rebellions, in the eighteenth and first half of the nineteenth century that collective resistance to fiscal innovations continued, while struggles over food supply and common rights increased. In general, the interests at play were those of small local units, especially peasant communities. The growth of capitalism and the expansion of the state required the "liberation" of resources over which the needs of the local unit had exercised priority. The Revolution played the dialectical role of accelerating the threat while increasing the chances for resistance to it.

At the level of the repertoire of collective action, the century from 1750 to 1850 brought an amplification and elaboration of the means available to people without eliminating any of the principal forms of action already in existence at the beginning of the period. It was the second half of the nineteenth century that brought the disappearance of the charivari, the classic food riot, the armed rebellion against the tax collector, and even the intervillage brawl. During the previous hundred years, in contrast, we see the appearance of the demonstration, the development of the strike, the rise of the deliberately-called meeting as means and context of action. Despite the defensive orientation of an important part of the period's collective actions, the means of offensive collective action were forming. They were forming on an enlarged scale, on the base of new sorts of organizations. The Revolution again played a contradictory role. Although the revolutionary legislation opposed special-interest associations, the experience of popular assemblies, revolutionary associations and national elections provided a model and, to some degree, a guarantee for action organized around a collective interest.

\section{Rural Conflicts Before and After}

The experience of Burgundy again gives us some concrete illustrations of these general processes. In rural Burgundy, the collective action of the eighteenth century had a strong anticapitalist orientation. It was, as we have already seen, the golden age of food riots. The crises of 1709, 1758 and 1775 brought their clusters of conflicts, and others appeared in between the great crises. That is the meaning of the 1770 edict of the Parlement of Burgundy which, like so many other edicts of the period, forbade anyone "to gather and stop wagons loaded with wheat or other grain, on roads, in cities, towns or villages, on pain of special prosecution..." (A. D. Côte d'Or C 81). That blockage of grain expressed the demand of ordinary people that the needs of the community have priority over the requirements of the market. The market, and therefore the merchants as well. 
The second common form of anticapitalist action was less routine and more ironic. It was local resistance to the landlords' consolidation of lands and of rights in the land. The irony lies in our normal readiness to place the landlords themselves in the anticapitalist camp. As the great regional historian Pierre de Saint-Jacob showed, the Burgundian landlords of the periodincluding both the "old" nobility and the ennobled officials and merchantsplayed the capitalist game by seizing the forests, usurping common lands, enclosing fields and insisting on collecting all the use fees to which their manors gave them claim. Rural people fought back. Suits against landlords multiplied, a fact which de Saint-Jacob interprets as evidence not only of seigniorial aggression but also of an increasing liberation of the peasants from traditional respect. (Emmanuel Le Roy Ladurie bids up the argument by writing of a "politicization" of peasant resistance in Burgundy. ${ }^{6}$ )

Where the lawsuit was impossible or ineffective, peasants resisted the seizure of commons by occupying them, resisted enclosures by breaking the hedges or fences. As Pierre de Saint-Jacob describes it:

The wardens of Athie were attacked by the people of Viserny for trying to forbid entry to a shepherd. On the lands of Bernard de Fontette, Pierre César du Crest, the lord of Saint-Aubin, organized an unusual expedition. He went with 17 men armed with "guns, stakes and staves" to break down the enclosures. They led in 40 cattle under the protection of two guards "with guns and hunting dogs," and kept the tenants of Bernard de Fontette from bringing in their cattle. In Charmois, at the urging of two women, a band of peasants went to break down a fence set up by the overseer of Grenand who could do nothing but watch and receive the jeers of the crowd. In Panthier, a merchant wanted to enclose his meadow; he got authorization from the local court. People assembled in the square and decided to break the hedges, which was done that night. They led in the horses. The merchant wanted to chase them away, but the young people who were guarding them stopped him, 'saying that they were on their own property, in a public meadow, that they had broken the enclosures and that they would break them again ...,7

As we can see, the opposition was not directed specifically against the landed nobility, but against the landlords of any class who chewed at the collective rights of the rural community. If in Longecourt in 1764 it was the lord who demanded his own share of the commons, in Darois two years later the Chapter of Sainte-Chapelle, in Dijon, tried to take a share of the communal 
woods, and in Villy-le-Brûlé in 1769 it was a farmer-notary who enclosed a meadow only to see the ditches filled in by the local people (A. D. Côte D'Or C 509, C 543, C 1552).

What a contrast with rural collective action after the Revolution! Food riots did survive until the middle of the nineteenth century. For example, in April 1829 a crowd in Châtillon forced M. Beaudoin, operator of a flour mill, to sell his wheat at 5 francs and 25 sous per double bushel, when he had posted the price at 5F30 (A. D. Côte d'Or M 8 II 4). At the next market, several brigades of gendarmes were on hand to prevent such "disorders" (A.D. Côte d'Or 8 M 27). Although the food riot continued to flourish, post-revolutionary rural struggles bore hardly a trace of the resistance against the landlords. Instead they concerned the policies, and especially the fiscal policies, of the state.

The active groups of the nineteenth century came especially from the small landholders and the workers of the commercialized, fully capitalist vineyards. Robert Laurent portrays that sort of protest as it took place just after the Revolution of 1830 :

... in September, the announcement of the resumption of the inventory of wine on the premises of winegrowers started turbulent demonstrations, near-riots, in Beaune. On the 12th of September at the time of the National Guard review 'cries of anger against the Revenue Administration [La Régie] rose from its very ranks.' Told that the residents of the suburbs planned to go to the tax offices in order to burn the registers as they had in 1814 , the mayor thought it prudent that evening to call the artillery company to arms and convoke part of the National Guard for 5 o'clock the next morning. On the 13th, toward 8 A.M., 'a huge crowd of winegrowers and workers,' shouting 'down with the wolves, down with excise taxes,' occupied the city hall square. To calm the demonstrators the mayor had to send the National Guard home at once. 'The crowd then dispersed gradually'.

Despite that peaceful dispersal, the authorities had to delay the inventory of wine. In Meursault it was less peaceful: the winegrowers drove out the tax men.

What is more, the anti-tax movement connected directly to political movements. The winegrowing area stood out for its republicanism; that was especially true of the hinterlands of Dijon and Beaune. In fact, we have already had a foretaste of the Burgundian flavor: the search of newspaper 
offices which incited the serenade and the charivari of September 1833 had to do with the Patriote de la Côte d'Or. The newspaper was being prosecuted for promoting resistance to tax collection. Etienne Cabet, deputy of the vineyard region, took up the defense of the newspaper. And during the Cabetian serenade of November 1833, people shouted not only "Long live the Republic" but also "Down with the excise taxes."

\section{What Was Changing?}

All things considered, we observe a significant transformation of the repertoire of collective action in Burgundy. As compared with the means of action prevailing before the Revolution, those of the nineteenth century were less tied to a communal base, more attached to national politics. Associations, clubs, societies played an increasing part. Yet there were important continuities: the survival of the charvari, the food riot, the classic anti-tax rebellion; the persistent orientation to the protection of local interests against the claims of the state and the market rather than to the creation of a better future. The old regime repertoire of collective action survived the Revolution. The forms of action themselves altered, adapted to new conditions; among other things, we notice a sort of politicization of all the forms. New forms of collective action arose; so far we have noticed especially the appearance of the demonstration as a distinctive means of action. Later we shall see the strike taking on importance as well. That hundred years spanning the Revolution was a period of transformation and growth of the means of collective action.

What of the Revolution's place in that transformation and growth of the means of collective action? The Revolution brought an extraordinary level of collective action, a politicization of all interests and thus of almost all the means of action, a centralization of power and thus of struggles for power, a frenzy of association and thus of action on the basis of associations, a promotion of the conditions for the development of capitalism and bourgeois hegemony and thus of a mounting threat to non-capitalist, non-bourgeois interests. If that summary is correct, the Revolution acted as a fundamental stage in the course of a transformation far longer and larger than the Revolution itself. Like the seventeenth-century consolidation of the national state, the changes of the Revolution led to a significant alteration of the prevailing modes of popular collective action.

The evolution of collective action had not ended, however. Although the Dijon winegrowers' demonstrations of the 1830 s certainly display many more familiar features than the Lanturelus of the 1630s, they also show their age. Nowadays, the successors of those winegrowers typically assemble outside the 
departmental capital, grouped around placards and banners identifying their organizations and summarizing their demands. The classic charivari and food riot have vanished, along with a number of other forms of action which persisted into the nineteenth century. Today's large-scale actions are even more heavily concentrated in Dijon, Beaune and other cities than they were in the 1830s. Labor unions and political parties often appear in the action. Although prices and taxes continue to be frequent causes for complaint, such exotic questions as American warmaking in Vietnam and the future of students in sports and physical education exercise many a crowd. As the world has changed, so has its collective action.

\section{The Twentieth Century}

In order to find the twentieth-century equivalent of the old Series I of the municipal archives, we have to walk the few blocks to the departmental archives, or even take the three-hour train trip to Paris for an exploration of the national archives. With the Revolution and especially with the building of a national police apparatus under Napoleon, three important changes occurred. First, the surveillance, control and repression of collective action became the business of specialized local representatives of the national government: policemen, prosecutors, spies, and others. Second, the procedures of surveillance, control and repression bureaucratized, routinized, became objects of regular reporting and inspection. Third, anticipatory surveillance greatly increased: the authorities watched groups carefully, to see what collective action they might take in the future, and to be ready for it. The user of French archives notices these changes in a significant expansion of the documentation available, and a significant displacement from the files of the many local old-regime authorities which had some jurisdiction over collective action to the files of a relatively small number of agencies of the national government. That is why the departmental and national archives yield so much more of our nineteenth- and twentieth-century evidence.

Bundle SM 3530 of the Côte d'Or departmental archives illustrates all these points. SM 3530 contains reports of commissaires de police, regional police officials, from 1914 through 1922. On the whole, SM 3530 is less exotic than its old-regime predecessors. The reports describe nothing so splendid as the 1564 entry into Dijon by Charles IX, when no fewer than twenty-three painters were among the hundreds of people paid for helping prepare the "works and mysteries necessary for the arrival and entry of the King" (A. M. Dijon I 18), or the 1766 city hall concert in honor of the Prince of Condé, which featured the prodigious Mozart children from Salzburg (A. M. Dijon B 400). They do, however, tell us of General Pershing's arrival in 1919 (he 
and Col. Howlet, the local American commander, dined at the Hôtel de la Cloche; alas, no "works and mysteries" were performed) and of the allegedly antipatriotic performance by music-hall star Montéhus in 1917. (While Dijon's Le Bien du Peuple declared that Montéhus had proposed "civil war after the fighting had ended," the five off-duty policemen in the audience who were later interrogated said Montéhus had told the crowd that although he was still a revolutionary socialist, politics would have to wait while there was a war on.) By contrast with the cramped handwritten minutes and elegantly penned proclamations of the seventeenth century, these twentiethcentury dossiers contain many typewritten reports, some telegrams, occasional notes of telephone conversations, scattered newspaper clippings and a few standard printed forms. As archeological specimens, they clearly belong to our own era.

Those are only their most superficial ties to the twentieth century. The dossiers of SM 3530 also provide clear traces of the great events of the time: the World War appears in such guises as the antiwar demonstrations of 1914 and the ceremonies, on the Fourth of July 1918, renaming the Place du Peuple as the Place du Président Wilson. The Russian Revolution shows up in 1918 in the form of "Bolshevist propaganda" spread by the detachment of 220 Russian soldiers at Dijon and by a few Russian civilians in the city. The national split of the labor movement into Communist and Socialist branches leaves its mark in the 1922 fractionation of the departmental labor federation. The major events of political history have their immediate counterparts in the stream of collective action gauged by the local police.

The reports of 28 July 1914 give a sense of the twentieth-century tone:

This evening, toward 6 p.m., a group of about a hundred workers, composed mainly of Spaniards and Italians and also of young people from the city aged 16 to 18 , almost all of them workers at the Petit Bernard glassworks, formed spontaneously into a parade at the Place du Peuple and, passing through Chabot Charny and Liberté streets, went to the Place Darcy, shouting 'Down with war! We want peace!' Because the demonstration was growing from moment to moment and because it seemed to be of a kind which would produce disorder in the streets and agitate popular feeling, I immediately took the necessary measures to stop the demonstration and, with the aid of a number of the available police, I managed to disperse the demonstrators at the Place Darcy and on the Boulevard de Sévigné, and by 7:20 calm had returned.

The inspector's helpers had picked up the group's marching orders, which 
read "Calm. Don't resist the police, disperse. In case of breakup, reform at the corner of Le Miroir. If broken up again, reform in front of Le Progrès, then in front of Le Bien Public. No shouts, no singing. In front of Le Progrès, only one shout: Vive la paix."

To anyone who has taken part in twentieth-century demonstrations, both sides of the story are wearily familiar. Despite his allusion to "spontaneity," the police inspector recognizes the event as an unauthorized demonstration, and takes the standard steps to check it. The glassworkers, on their side, anticipate the reaction of the police, and make contingency plans. The players know their stage directions, although the script leaves plenty of room for improvisation, and no one is sure how it will end. The demonstrators want to assemble as many people as possible in a visible and symbolically significant public place, and to display their common devotion to a single welldefined program. The event shares some properties with the Lanturelu of 1630 , the serenade of 1790 , the political charivari of 1830 . It bears a much greater resemblance to the winegrowers' tax protest of 1830 . It is the full-fledged demonstration, a variety of collective action which germinated in the nineteenth century and flowered in the twentieth.

Demonstrations, strikes and public meetings dominate the publicly-visible actions reported in SM 3530 over the whole period from 1914 to 1922. By Bastille Day 1921 the themes of peace and internationalism had returned to prominence after their dissolution in World War I. On the morning of that holiday the "communist socialists" of Dijon organized a march to the city's cemetery. 150 to 200 people (including some 20 women) gathered at the Place du Président Wilson. Young people distributed handbills as they paraded. At the head of the procession came three dignitaries from the labor exchange, the editor of the socialist newspaper, a former deputy and a departmental council member. "Next came twenty children carrying flowers and three red flags representing the A.R.A.C., the union federation and the socialist party, then six signs saying WAR AGAINST WAR, WE HATE HATRED, AMNESTY, HANDS ACROSS THE BORDER, THOU SHALT NOT KILL (JESUS), THEY HAVE CLAIMS ON US (CLEMENCEAU)." Leaders of the movement gave speeches at the 1870-71 war monument, and members of the crowd ceremoniously laid out three bouquets-one each for the French, Italian and German dead. "The banners were folded up," the inspector tells us, "and the crowd left the cemetery without incident at 11.30 a.m."

In the midst of this series of reports come periodic appraisals of local "public spirit." Esprit public refers especially to the likely intensity and direction of 
collective action on the part of different parts of the population. The job of the spies, informers and observers employed by the police is to gauge and document those likelihoods. In 1918, we find our inspector reporting to the public prosecutor that

The world of factory and shop workers is complaining about the cost of living but has not been too hard hit so far by the new controls. In any case, they are willing to do their part... The three groups of railroad workers (trains, roadbed and operations) are holding secret meetings, and talking about occupational questions; they expect a follow-through on the promises made to them; that looks to me like a sore point which could bring on some agitation in the future if they don't receive satisfaction. In my opinion it would be a good idea to resolve the question of special compensation as soon as possible.

Nothing unusual about all this. That is the point: by 1918, we have a police force routinely scanning the world of workers, students and political activists for any signs of "agitation," any predictors of concerted action. That same police force has developed standard procedures for monitoring, containing and, on occasion, breaking up meetings, demonstrations and strikes when they do occur. Its business is repression.

By comparison with the nineteenth century, these twentieth-century actions are large in scale, strongly tied to formal organizations pursuing defined public programs, closely monitored by the police. Their variety and color appear to have diminished: the charivari and its companion forms of street theater, for example, disappeared from the popular repertoire without replacement. Popular collective action channeled itself into meetings, strikes, demonstrations and a few related types of gathering. These recent changes all continue trends which were clearly visible by the middle of the nineteenth century. The same sorts of changes in interest, organization and opportunity that we have seen in the nineteenth century continued in the twentieth: increasing state control of essential decisions and resources, expanding importance of special-interest associations, growing range of governmental surveillance, and so on. In the perspective of the last three or four centuries, the period since the Revolution of 1848 is definitely of a piece.

\section{Long-Run Changes in Collective Action}

The chronology of collective action which emerges from our exploration of Burgundy has some surprises in it. If the Revolution of 1789 was not a hinge but a milestone, the less momentous Revolution of 1848 has some claim to 
be a hinge: a greater change in the character and direction of collective action occurred in the middle of the nineteenth century than at the end of the eighteenth. To find a comparable transition, we must look back to the middle of the seventeenth century, the period of the Fronde. Then, as in the nineteenth century, a great expansion and centralization of state power altered the character of contention for power. In Burgundy, as elsewhere, the transition showed up first and most visibly as a series of rebellions against new and expanded taxation. The Lanturelu of 1630 is a case in point. From that time on, Burgundy and most of France moved into two centuries of intermittent popular resistance to the expansion of state power and the growth of capitalist property relations. Anti-conscription movements, food riots, invasions of fields, further tax rebellions started that popular resistance.

People had fought taxes and military service long before 1630 . The midseventeenth century nevertheless served as a hinge in the history of collective action. Before that point local authorities and regional magnates were often available as allies; in popular rebellion they saw the means of retaining their liberties or expanding their power. The great rebellions of the seventeenth century all built on the complicity or active support of local authorities and regional magnates. Starting with the repression of the Fronde, Louis XIV and his ministers managed to check, coopt, replace or liquidate most of their regional rivals. After swelling in the seventeenth century, with considerable support from authorities and magnates, popular resistance continued on its own for two centuries more. It changed form as interests, organization and opportunity shifted. We have noticed the durable rise of the food riot at the end of the seventeenth century, as the pressure on communities to surrender local grain reserves to the demands of the national market increased, and gained the support of royal officials. We have seen the rise and fall of rural efforts to defend communal rights to glean or pasture against the efforts of landlords to consolidate their holdings and make their property claims exclusive. This sort of resistance to the claims of the state and the demands of capitalism persisted unabated into the nineteenth century.

The nineteenth-century transition brought a great and rapid decline in the two-hundred-year-old resistance to statemaking and capitalism. Although the mobilization and politicization of the 1789 Revolution anticipated some of its effects, the Revolution of 1848 marked-and helped produce-a major swing away from the defense of local interests against the expansion of the state and of capitalism, toward popular efforts to organize around interests on a relatively large scale and to seize some control over the state and over the means of production. We have noticed the virtual disappearance of the food riot and the old style of tax rebellion, the flourishing of the strike, of 
the demonstration, and of the public meeting as means of collective action.

The incentives for analyzing the history of collective action, instead of contenting ourselves with the collective action of our own time, go beyond the desire to understand the past in its own terms. The past helped create the present; knowledge of the impact of the expanding seventeenth-century state on the interests, hopes and grievances of ordinary Frenchmen will help us identify the durable features of that state and of its impact on collective action. If we are so foolish as to seek generalizations about the influence of statemaking-or of industrialization, or of urbanization, or of the expansion of capitalism-on prevailing patterns of collective action, we have no choice but to look at big blocks of historical experience in which statemaking, industrialization, urbanization or the expansion of capitalism were actually occurring. Just such a foolish, absorbing search brought me to Dijon to leaf through seventeenth-century police reports and watch students march through the streets outside the archives.

\section{NOTES}

1. H. Millot, Le comité permanent de Dijon, juillet 1789-février 1790, "La Révolution en Côte d'Or," new series, no. 1 (Dijon, 1925), pp. 147-148.

2. Colin Lucas, The Structure of the Terror: The Example of Javogues and the Loire (London, 1973).

3. Harvey Mitchell, "The Vendée and Counterrevolution: A Review Essay," French Historical Studies 5 (1968), pp. 405-429.

4. Albert Soboul, Précis d'Histoire de la Révolution Française (Paris, 1962), p. 520.

5. Yves-Marie Bercé, Croquants et nu-pieds. Les soulèvements paysans en France du XVIe au XIXe siècle (Paris, 1974), p. 162.

6. Emmanuel Le Roy Ladurie, "Révoltes et contestations rurales en France de 1675 à 1788," Annales; Economies, Societes, Civilisations 29 (1974), pp. 6-22.

7. Pierre de Saint-Jacob, Les paysans du Bourgogne du Nord (Paris, 1960), pp. 370371.

8. Robert Laurent, Les Vignerons de la 'Côte d'Or'au dix-neuvième siècle (Paris, 1957), pp. $484-485$. 